\title{
BENTUK PENYAJIAN MUSIK GAMELAN PADA TARI SEINGGOK SEPEMUNYIAN DI SANGGAR SEINGGOK SEPEMUNYIAN KOTA PRABUMULIH
}

\author{
Ranita Anggraini ${ }^{1}$, A Heyanto ${ }^{2)}$, Nofroza Yelli $^{3)}$ \\ 1), 2), 3) Prodi Pendidikan Seni Pertunjukan, Universitas PGRI Palembang \\ Jl. Jend. A. Yani. Lrg. Gotong Royong 9/10 Ulu Palembang
}

Email; Ranitaanggrini29@gmail.com ${ }^{l)}$,yelliumboro@gmail.co2 ${ }^{3)}$

\begin{abstract}
The problem in this research is how the form of Gamelan Music Presentation in Seinggok Sepemunyian Dance at Sanggar Seinggok Sepemunyian, Prabumulih City. The purpose of this study was to determine and describe the form of presenting gamelan music in the Seinggok Sepemunyian dance at Sanggar Seinggok Sepemunyian, Prabumulih City. The method used in this research is descriptive qualitative. This research was conducted at Sanggar Seinggok Sepemunyian, Prabumulih City. In this study, researchers used data collection techniques by means of observation, interviews and documentation. The technique used is 1) the observation technique, namely observing directly the form of gamelan music in the presentation of the seinggok sepemunyian dance, 2) the interview technique is carried out by giving questions to the source who knows a lot about gamelan music, as well as the management of the Seinggok Sepemunyian Studio. 3) documentation technique, namely collecting data in the form of documents related to gamelan music in the presentation of the Seinggok Sepemunyian dance including audio and visual data. The results of this study indicate that Sanggar Seinggok Sepemunyian in gamelan music in the presentation of the Seinggok Sepemunyian dance tells about musical performances that will start until the end of the music show and the Seinggok Sepemunyian Dance is complete, where there is a musical concept in playing musical instruments such as drums face two.
\end{abstract}

Keywords: Gamelan Music Presentation Form, Sanggar Seinggok Sepemunyian

\begin{abstract}
ABSTRAK
Permasalahan dalam penelitian ini adalah bagaimana Bentuk Penyajian Musik Gamelan Pada Tari Seinggok Sepemunyian di Sanggar Seinggok Sepemunyian Kota Prabumulih. Tujuan dalam penelitian ini untuk mengetahui dan mendeskripsikan bentuk penyajian musik gamelan pada Tari Seinggok Sepemunyian di Sanggar Seinggok Sepemunyian Kota Prabumulih. Metode yang digunakan dalam penelitian ini yaitu kualitatif yang bersifat deskriftif. Penelitian ini dilakukan di Sanggar Seinggok Sepemunyian Kota Prabumulih. Pada penelitian ini peneliti menggunakan teknik pengumpulan data dengan cara observasi, wawancara dan dokumentasi. Teknik yang digunakan adalah 1) teknik observasi yakni mengamati secara langsung bentuk musik gamelan pada penyajian tari seinggok sepemunyian. 2) teknik wawancara dilakukan dengan memberikan pertanyaan kepada narasumber yang banyak mengetahui tentang musik gamelan, juga pengurus Sanggar Seinggok Sepemunyian. 3) teknik dokumentasi yaitu mengumpulkan data-data berupa dokumen terkait dengan musik gamelan pada penyajian tari Seinggok Sepemunyian diantaranya data audio dan visual. Hasil penelitian ini menunjukkan bahwa Sanggar Seinggok Sepemunyian dalam musik gamelan pada penyajian tari seinggok sepemunyian itu menceritakan tentang pertunjukan musik yang akan dimulai hingga akhir pertunjukan musik dan Tari Seinggok Sepemunyian selesai yang terdapat konsep musik didalam memainkan alat musik seperti gong, kenong, tawak-tawak dan gendang muka dua.
\end{abstract}

Kata Kunci: Bentuk Penyajian Musik Gamelan, Sanggar Seinggok Sepemunyian 


\section{Pendahuluan}

Tari Seinggok Sepemunyian merupakan tari sambut Kota Prabumulih yang biasa di pertunjukan pada saat penyambutan tamu-tamu agung, pelaksanaan pernikahan dan pesta rakyat. Tarian ini diiringi dengan beberapa alat musik Gamelan yaitu (gong, kenong, tawak-tawak, dan gendang muka dua). Gamelan merupakan ensambel musik yang biasanya menggunakan metalofon, gambang, gendang dan gong istilah gamelan merujuk pada instrument/alatnya yang mana satu kesatuan utuh yang di wujudkan dan bunyinya bersama. Setiap daerah memiliki alat musik gamelan yang berbeda begitu pula dengan alat musik yang ada dikota prabumulih.

Gamelan yang mengiringi tari sambut Seinggok Sepemunyian ini sedikit memiliki perbedaan dengan Gamelan yang ada di daerah lain. Jika diamati dari bentuk fisiknya seperti bentuk Gamelan yang ada di daerah lain. Berdasarkan cara memainkannya alat musik Gamelan ini sama seperti Gamelan pada umumnya. Perbedaan alat musik Gamelan yang ada di Kota Prabumulih memiliki nada yang berbeda dengan Gamelan yang ada di daerah lainnya.

Nada yang dihasilkan pada Gamelan ini sedikit lebih lembut. Gamelan pada pengiring tarian ini sudah melalui proses yang panjang mungkin puluhan tahun dahulu. Jika membuat yang baru nadanya akan beda dengan nada yang sekarang saat ini. maka gamelan tersebut tetap di pertahankan sampai saat ini.

Pelestarian musik Gamelan ini tentunya tidak saja dilakukan oleh pemerintah dan para senimannya (Sanggar Seinggok Sepemunyian), masyarakat juga ikut andil dalam menjaganya. Dari penjelasan tersebut, peneliti sebagai salah seorang generasi daerah Kota Prabumulih sangat perlu ikut andil dalam melestarikan dan mengembangkan musik Gamelan ini. Jika pemerintah melestarikan dengan mendirikan beberapa sanggar dan masyarakat melestarikannya dengan lisan secara turun temurun.

Maka peneliti dalam melestarikan musik Gamelan ini harus dengan tulisan. Untuk melestarikan dan mengembangkan musik Gamelan melalui tulisan, tentunya penulis harus meneliti, dan mengetahui secara detail terlebih dahulu tentang bentuk penyajian musik Gamelan pada tari seinggok sepemunyian tersebut. Artinya, kondisi inilah yang membuat peneliti tertarik untuk mengankat permasalahan ini sebagai bahan penulisan skripsi. Sehingga penulisan tentang Bentuk Penyajian Musik Gamelan Pada Tari Sambut Seinggok Sepemunyian Di Sanggar Seinggok Sepemunyian Kota Prabumulih dapat dijadikan sebagai sumber untuk mengembangkan kesenian alat musik Gamelan.

Adapun tujuan penelitian ini untuk mengetahui bagaimana Bentuk Penyajian Musik Gamelan Pada Tari Seinggok Sepemunyian di Sanggar Seinggok Sepemunyian Kota Prabumulih. Dalam penelitian ini peneliti menggunakan metode penelitian kualitatif, yang merupakan salah satu penelitian yang bertujuan untuk mendapatkan pemahaman tentang kenyataan melalui proses berfikir induktif. Menurut (Mardalis, 1995, p. 24) metode diartikan sebagai suatu cara atau teknis yang dilakukan dalam proses penelitian. Sedangkan penelitian itu sendiri diartikan sebagai upaya dalam bidang ilmu pengetahuan yang dijalankan untuk memperoleh faktafakta dan prinsip-prinsip dengan sabar, hati-hati dan sistematis untuk mewujudkan kebenaran. Menurut (Sugiyono, 2018, p. 6) secara umum metode penelitian diartikan sebagai cara ilmiah untuk mendapatkan data dengan tujuan dan kegunaan tertentu.

Adapun penelitian yang digunakan dalam penelitian ini adalah metode deskiptif kualitatif. Menurut (Sugiyono, Metode Penelitian Kombinasi (Mix Methods), 2015, p. 15) metode penelitian kualitatif adalah metode penelitian yang berlandaskan pada filsafat postpositivisme, digunakan untuk meneliti pada kondisi objek yang alamiah, (sebagai lawannya adalah eksperimen) dimana peneliti adalah sebagai instrument kunci, pengambilan sampel sumber data dilakukan secara purposive dan snowball, teknik pengumpulan dengan tringgulasi (gabungan), analisis data bersifat induktif/kualitatif, dan hasil penelitian kualitataif lebih menekankan makna dari pada generalisasi.

\section{Landasan Teori}

1. Musik

Musik dapat di definisikan sebagai sebuah cetusan ekspresi atau pikiran yang dikeluarkan secara teratur dalam bentuk bunyi. Asal kata musik berasal dari bahasa Yunani yaitu mousike yang diambil dari nama dewa dalam mitoligi yunani kuno yaitu mousa yakni yang memimpin seni dan ilmu (Indonesia, 1996, p. 413). Tradisional berasal dari kata tradition (Latin) yang berarti kebiasaan yang sifatnya turun temurun. Kata tradisional itu sendiri adalah sifat yang berarti berpegang teguh terhadap kebiasaan yang turun temurun (Salim, 1991, p. 1636). Peneliti menyimpulkan dari pengertian diatas, bahwa pengertian musik adalah sebuah karya seni yang didasari bunyi atau suara yang diungkapkan melalui alat musik yang menggandung unsur keindahan.

\section{Musik Tradisional}

Menurut (Sedyawati, 1992, p. 23) musik tradisional adalah musik yang digunakan sebagai perwujudan dan nilai budaya yang sesusai dengan tradisi. Musik tradisional menurut (Tumbijo, 1977, p. 13) adalah seni budaya yang sejak lama turun temurun telah hidup dan berkembang pada daerah tertentu. Maka dapat dijelaskan bahwa musik tradisional adalah musik masyarakat yang diwariskan secara turun-temurun dan berkelanjutan pada masyarakat suatu daerah. Kesenian tradisonal pada umumnya juga tidak dapat diketahui secara pasti kapan dan siapa penciptanya. Hal ini dikarenakan kesenian tradisonal atau kesenian rakyat bukan merupakan hasil kreatifitas individu, tetapi tercipta secara anonim bersama kreatifitas masyarakat yang mendukungnya.

Seni selalu melekat pada diri tiap-tiap orang, seperti: seni tari, seni musik, seni rupa, seni sastra dan seni-seni yang lain karena telah menyatu di dalam kehidupan sehari-hari, baik di dalam lingkungan keluarga maupun lingkungan masyarakat luas. 
Manusia tidak dapat terlepas dari seni karena seni merupakan salah satu kebudayaan yang mengandung nilai indah (estetis) sedangkan setiap manusia menyukai keindahan. Seni selalu mengandung ide-ide yang dinyatakan dalam aktivitas atau rupa sebagai lambang. Menurut (Wardhana, 1990, p. 32) bahwa seni adalah buah budi manusia dalam pernyataan nilai-nilai keindahan dan keluhuran, berfungsi sebagai pembawa keseimbangan antara lingkaran budaya fisik dan psikis.

Kesimpulan peneliti yaitu musik tradisional adalah musik yang sangat berkaitan pada tradisi masyarakat tertentu. Maksudnya musik yang merupakan peninggalan dari nenek moyang dilestarikan hingga masa kini yang di mainkan menggunakan alat musik jaman dahulu yaitu alat musik gamelan yang terdiri dari, gong, kenong, tawak-tawak, dan gendang muka dua.

\section{Unsur Seni Musik}

Musik terdiri atas beberapa unsur dasar, diantaranya melodi, irama, tempo dan harmoni.

a. Melodi berasal dari bahasa Yunani, meloidia, yang berati "bernyanyi" atau "berteriak" (Oktara, 2011, p. 81). Sementara secara harfiah, melodi adalah susunan rangkaian tiga nada atau lebih yang terdengar berurutan secara logis serta memiliki irama dan berisi ungkapan suatu gagasan (Oktara, 2011, p. 81). Melodi merupakan rangkaian dari sejumlah nada atau bunyi, yang ditanggapi berdasarkan perbedaan tinggi-rendah atau naik-turunnya. Dapat merupakan satu ungkapan penuh, atau hanya berupa penggalan ungkapan (Soeharto, 1992, p. 80).

a. Irama / Ritme

Istilah ritme lebih menekankan pada unsur musik yang tidak berkaitan langsung dengan pitch (tinggi rendah suara), tetapi lebih mengarah pada panjang pendeknya durasi (Kusumawati, 2004, p. 1). Irama yaitu pola ritme (derap langkah teratur) yang dinyatakan dengan nama, seperti: wals, mars, bossanova dan lainlain (Banoe, 2003, p. 198). Irama yaitu gerak yang teratur mengalir, karena munculnya aksen secara tetap. Keindahannya akan lebih terasa oleh adanya jalinan perbedaan nilai dari satuan-satuan bunyinya (Soeharto, 1992, p. 56).

b. Tempo

Tempo dikenal sebagai cepat lambatnya suatu lagu dimainkan. Menurut (Mudjilah, 2004, p. 7) tempo adalah kecepatan dimana kita mengetuk / menghitung panjang not. Tempo adalah cepat lambatnya gerak musik (Soeharto, 1992, p. 134). Tempo merupakan waktu; kecepatan; kecepatan dalam ukuran langkah tertentu; kecepatan dengan memperbandingkan gerak atau gerak tari tertentu (Banoe, 2003, p. 410).

c. Harmoni

Harmoni merupakan ilmu pengetahuan tentang harmoni; cabang ilmu pengetahuan musik yang membahas dan membicarakan perihal keindahan komposisi musik (Banoe, 2003, p. 180). Harmoni merupakan perihal keselarasan paduan bunyi. Secara teknis meliputi susunan, peranan, dan hubungan dari sebuah paduan bunyi dengan sesamanya, atau dengan bentuk keseluruhannya (Soeharto, 1992, p. 48).

4. Musik Gamelan

Dalam Kamus besar bahasa indonesia (Nasional, 1988, p. 251) gamelan didefinisikan sebagai "Seperangkat alat musik jawa (sunda, Bali) yang terdiri atas saron, bonang, gambang, rebab, gendang, gong dan sebagainya. Pertama Gamelan di artikan sebagai suatu sistem musikal, sedangkan yang kedua, Gamelan diartikan sebagai alat musik atau perangkat Gamelan (Waridi, 2005, p. 141) pada sub pembahasan disini pengertian gamelan di maknai sebagai alat musik yang terkenal di Indonesia alat musik yang satu ini sering kita jumpai pada beberapa kesenian tradisional di Indonesia.

Arti Gamelan sebenarnya berasal dari kata "Gamel" yang dalam bahasa jawa mempunyai arti memukul atau menabuh, sedangkan pada ahkiran kata ada imbuhan kata "an" yang berfungsi membentuk kata benda. Dengan begitu makna gamelan bisa diartikan sebagai kumpulan dari beberapa alat musik yang dimainkan dengan cara di pukul atau ditabuh.

a. Gendang muka dua, merupakan alat musik yang tidak bernada (ritmis) tetapi hanya memiliki perbedaan tinggi bunyi untuk menggeluarkan irama atau bisa disebut juga yang berfungsi mengatur irama. Macam-Macam Perangkat Gamelan Ukuran Gendang terdiri dari 3 jenis gendang yaitu:

1. Gendang Gedhe

2. Gendang Penanggulan

3. Gendang Gedhungan

b. Kenong, bentuk alat musik ini adalah bentuk alat musik yang paling gemuk dibangingkan kempul dan gong walapun besar kenong ini berbentuk cekungan dibagian tengahnya dibuat menonjol untuk ditabuh.

c. Gong, penanda permulaan dan ahkiran gendhing dan member rasa keseimbangan setelah berlalunya permainan gendhing yang panjang.

d. Tawak-Tawak, bentuknya sama dengan kelinang hanya ukurannya saja yang lebih besar. Panjang tawangnya berkisar antara $10-15 \mathrm{~cm}$. garis tengaah lingkaran tawang mencapai $40-50 \mathrm{~cm}$.

\section{Kajian Terdahulu Yang Relevan}

Peneliti membandingkan dengan penelitian yang relevan terhadap bentuk penyajian, seperti penelitian yang dilakukan A. Heriyanto, Dedy Firmansyah, Annisa Anggraeni 2020 meneliti tentang "Bentuk Penyajian Drumband SMA NEGRI 3 Unggulan Kayu Agung Ogan Komering Ilir”. Hasil Penelitian ini menunjukan bahwa musik drumband SMA 3 Unggulan Kayu Agung Ogan Komering Ilir ini terbagi menjadi (2) versi yaitu Delfi dan Display urutan penyajianya terdiri dari Bagian awal (Pampare), Bagian tengah (Mars dan Lagu) dan Bagian ahkir (Turun alat). 
Pada penelitian yang diteliti oleh A. Heriyanto, Dedy Firmansyah, Annisa Anggraeni, terdapat perbedaan pada bentuk penyajiannya sehingga menjadi bahan perbandingan bagi peneliti untuk melakukan penelitian sebagai bahan penulisan Peneliti yang dilakukan oleh A. Heriyanro, Dedy Firmansyah, Annisa Anggraeni yaitu meneliti Bentuk Penyajian Drumband sedangkan peneliti meneliti tentang bentuk penyajian musik gamelan pada tari seinggok sepemunyian. Adapun persamaan yang peneliti lakukan dengan peneliti sebelumnya sama-sama meneliti urutan dari awal sampai ahkir penyajian.

Pada penelitian yang dilakukan Diah Ayu Prianto (2015) Bentuk Penyajian Musik Gamelan Pada Kesenian Jaranan Di Sanggar Wahyu Turonggo Budoyo Desa Sumber Rahayu Kecamatan Rambang Kabupaten Muara Enim. Berdasarkan hasil penelitian yang dilakukan oleh Diah Ayu Putri Prianto yaitu hasil Penelitian ini menunjukan bahwa sanggar Wahyu Turonggo Budoyo dalam penyajian alat musik gamelan itu menceritakan tentang pertujukan musik yang akan dimulai hingga ahkir pertunjukan musik dan tari jaranan selesai yang terdapat konsep musik didalam memainkan alat musik seperti gong, kenong, saron, gendang, icik-icik, terompet dan sinden.

Dari penelitian yang dilakukan oleh Diah Ayu Putri Prianto banyak terdapat kerelevanan materi atau objek penelitian pada penelitian yang akan dilakukan yaitu, sama-sama meneliti tentang musik gamelan Diah Ayu Putri Prianto juga menggunakan metode deskriptif kualitatif. Perbedaan dengan penelitian yang akan dilakukan peneliti adalah Diah Ayu Putri Prianto meneliti dengan membahas tentang bentuk penyajian musik gamelan pada kesenian jaranan di sanggar wahyu turonggo budoyo desa sumber rahayu Kecamatan Rambang Kabupaten Muara enim. Sedangkan peneliti hanya fokus dengan bagaiman bentuk musik gamelan pada tari seinggok sepemunyian di sanggar seinggok sepemunyian Kota Prabumulih.

\section{Pembahasan}

\section{a. Alat musik}

Alat musik yang digunakan dalam musik Gamelan Tari Seinggok Sepemunyian terdiri dari kenong, Tawaktawak, Gendang bermuka dua, dan gong. Adapun Pengambaran musik Gamelan Pada Tari Seinggok Sepemunyian Sebagai Berikut :

1. Kenong

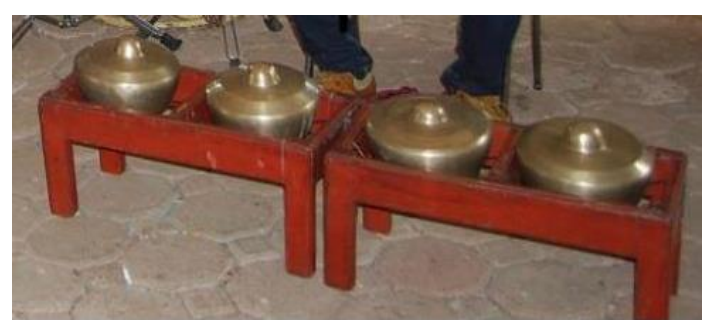

Gambar 1: Kenong

(Dokumentasi: Ranita, November 2020)
Kenong sebagai pembawa alur lagu dalam tarian, Kenong merupakan alat musik gamelan yang termasuk dalam keluarga 'pencon'. Kenong merupakan instrumen paling gemuk di antara keluarga pencon. Kenong disusun pada 'pangkon' berupa kayu yang dialasi dengan tali, sehingga tidak menghambat getaran kenong ketika ditabuh.Bentuk kenong yang besar menghasilkan suara yang rendah namun nyaring dengan timbre yang khas, suara kenong ditangkap berbunyi 'ning-nong', sehingga dinamakan alat musik 'kenong'. Notasi Kenong dalam musik panyajian tari Seinggok Sepemunyian:

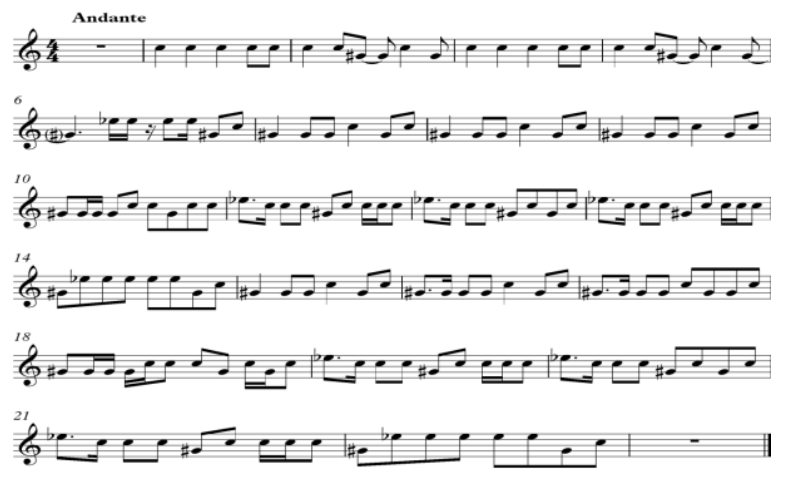

2. Tawak-tawak

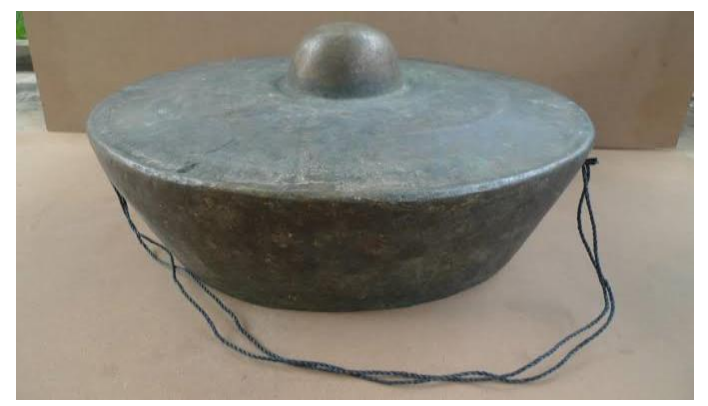

Gambar 2 : Tawak-Tawak

(Dokumentasi : Ranita, November 2020)

Tawak-tawak dalam musik Tari Seinggok Sepemunyian berfungsi mengisi kekosongan atau berpola rapat dalam musik tarian, Tawak-tawak adalah alat musik yang berbentuk seperti Gong tetapi berukuran lebih kecil dari gong dan berukuran lebih besar dibandingkan Canang. Berfungsi sebagai "peningkul" atau "peningkah" untuk merespon irama kenong sehingga suara musik tidak akan menjadi sumbang dengan adanya alat musik tawak-tawak. posisi tawaktawak akan digantung pada sebuah tali yang digantung pada tiang. Contoh notasi Notasi Tawak-tawakdalam musik Seinggok Sepemunyian:

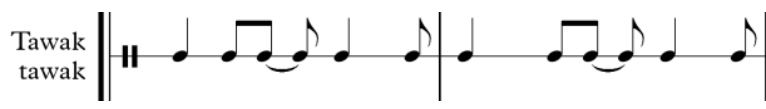


3. Gendang Bermuka Dua

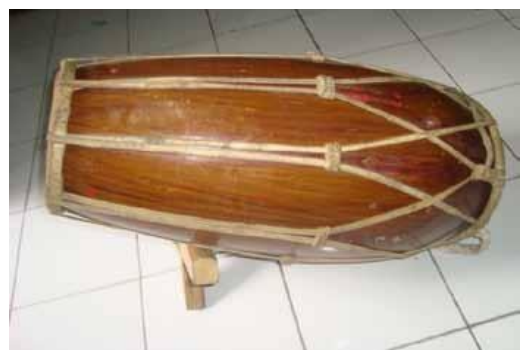

Gambar 3 : Gendang Muka Dua

(Dokumentasi : Ranita, November 2020)

Gendang bermuka dua berfungsi sebagai mengatur pola ketukan dalam irama langkah penari, gendang ini memiliki dua sisi artinya cara memainkan dengan tangan kanan dan kiri duduk bersila. Notasi Gendang Bermuka Dua dalam musik Tari Seinggok Sepemunyian:

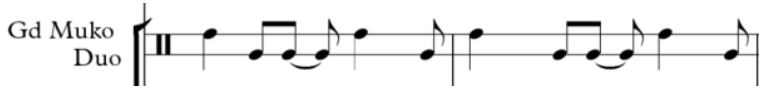

4. Gong

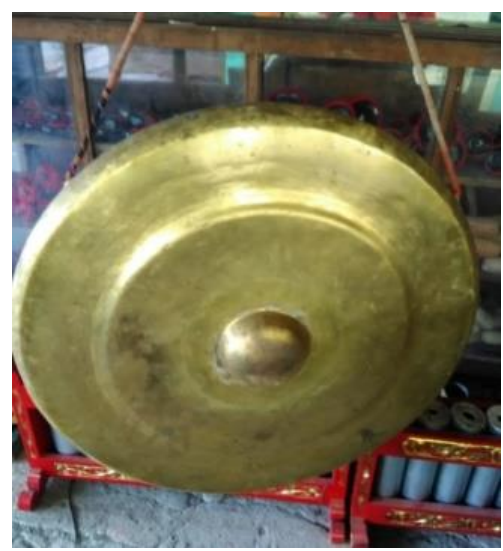

Gambar 4 : Gong

(Dokumentasi: Ranita, November 2020).

Gong berfungsi sebagai dalam seluruh bagian dalam musik tarian. Alat musik tradisional ini terbuat dari leburan logam, seperti perunggu dengan tembaga yang dibentuk sedemikian rupa hingga menyerupai piring raksasa yang memiliki poros cembung di bagian tengahnya. Gong secara umum terbagi menjadi salah satu dari tiga jenis: Gong yang ditangguhkan kurang lebih datar, cakram logam melingkar yang digantung secara vertikal dengan kabel yang dilewatkan melalui lubang di dekat tepi atas.

Bossed atau nipple gong memiliki bos tengah yang terangkat, atau kenop, dan sering ditangguhkan dan dimainkan secara horizontal. Gong mangkuk berbentuk mangkuk dan diletakkan di atas bantal. Yang terakhir dapat dianggap sebagai anggota kategori lonceng. Gong dibuat terutama dari perunggu atau kuningan tetapi ada banyak paduan lain yang digunakan. Gong menghasilkan dua jenis suara yang berbeda. Gong dengan permukaan datar yang pada dasarnya bergetar dalam berbagai mode, memberikan "benturan" daripada nada yang disetel. Kategori gong ini kadang-kadang disebut tamtam untuk membedakannya dari gong bos yang memberi nada yang disetel. Dalam ansambel gamelan Indonesia, beberapa bossed gong sengaja dibuat untuk menghasilkan nada ketukan tambahan dalam rentang sekitar 1 hingga $5 \mathrm{~Hz}$. Penggunaan istilah "gong" untuk kedua jenis alat musik ini adalah umum. Notasi Gong dalam musik Tari Seinggok Sepemunyian:

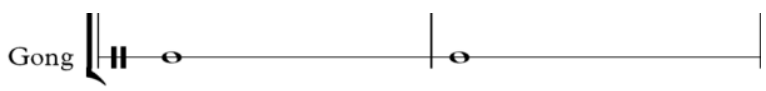

\section{b. Busana pemusik dan penari}

Busana yang digunakan pada tari seinggok sepemunyian di sanggar seinggok sepemunyian Kota Prabumulih dapat dilihat pada gambar berikut.

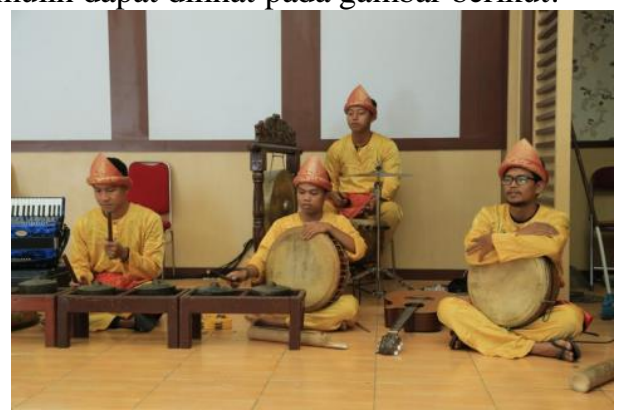

Gambar 5: Foto pemain musik gamelan pada penyajian tari seinggok sepemunyian

(Dokumentasi: Yucha Sanir November 2019).

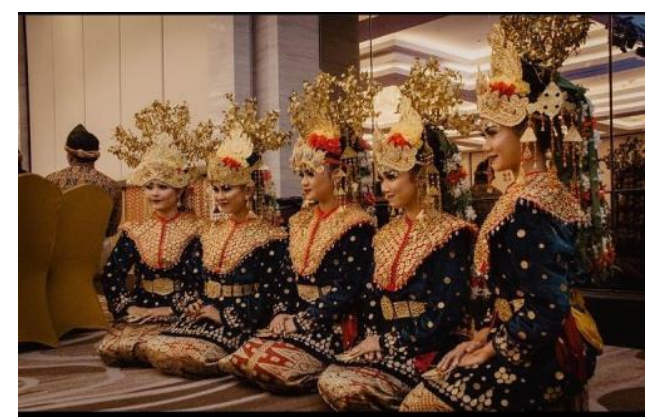

Gambar 6 : Foto Penari dan Busana Tari Seinggok Sepemunyian

(Dokumentasi: Yucha Sanir, November 2019)

\section{c. Bentuk Penyajian Musik Gamelan Pada Tari Seinggok Sepemunyian}

Peneliti Membahas tentang Bentuk Penyajian Musik Gamelan Pada Tari Seinggok Sepemunyian Di Sanggar Seinggok Sepemunyian Kota Prabumulih tarian ini merupakangabungan dari tiga suku yatitu Rambang, Belide, dan Lematangyang diiringi beberapa alat musik gamelan yaitu Gong, Kenong, Tawak-Tawak dan Gendang muka dua yang kurang lebih berumur 400 tahun yang lalu cerita dari Bpk. Ajadin salah satu seesepuh Kota Prabumulih. Dalam Pertunjukannya, musik gamelan ini dimainkan dalam bentuk ensambel karena dimainkan secara besama-sama atau kelompok. Jumlah pemain dalam musik gamelan ini 5 orang 
pemain. Adapun tempat dan waktu yang biasanya dilakukan bisa di tampilkan di dalam dan di luar ruangan. Bentuk penyajian musik gamelan pada tari seinggok sepemunyian ini biasa di pertunjukan pada acara penyambutan tamu-tamu agung, acara pernikahan dan pesta rakyat untuk menyaksikan pertunjukan penonton membentuk melingkar.

Pada pertunjukan musik gamelan ini menggunakan teori Bentuk terdiri dari unsur gerak tari, tata rias dan busana, musik pengiring, properti pertunjukan, waktu dan tempat pertunjukan serta menggunakan metode penelitian deskriptif kualitatif. Begitu juga pada teori A. Heriyanto, Dedy Firmansyah dan Annisa Anggraeini yang membahas tentang "Bentuk Penyajian Drumband SMA Negeri 3 Unggulan Kayu Agung Kabupaten Ogan Komering Ilir". Dengan menggunakan teori bentuk penyajian ini terbagi menjadi 2 versi yaitu Delfi dan Display yang menjelaskan urutan penyajiannya dari awal, bagian tengah, dan ahkir.yang memainkan satu atau beberapa lagu dengan menggunkan sejumlah kombinasi alat musik pada halaman Out door (panggung terbuka) atau In door (panggung arena) dan waktu penyajian serta menggunkan metode penelitian kualitatif. Namun Peneliti meneliti pertunjukan musik gamelan pada penyajian tari seinggok sepemunyian hingga ahkir pertunjukan selesai dalam musik gamelan guna untuk memberikan uraian yang jelas tentang penyajian musik agar lebih jelas dan akurat.

Awal cerita penyajian musik gamelan yang disajikan pada pertunjukan tari seinggok sepemunyian dimulai dari pukulan kenong yang diikuti dengan musik gamelan lainnya.Kemudian disambung dengan alunan musik Gong sebagai penanda awal masuknya instrument musik, lalu disambung secara bersama-sama dengan alat musik gendang, tawak-tawak yang dimainkan hingga durasi 11 menit 4 detik. Kemudian bunyi musik gendang, gong, tawak-tawak, gendang muka dua.Musik tersebut terus dimainkan alunan nada yang serentak seiring musik dimainkan, Penari memulai menari dengan berbaris berbentuk pormasi diiringi musik gamelan gendang, kenong, tawak-tawak, gendang muka dua dengan pola yang sama hingga penari selesai. Tari Seinggok Sepemunyian ini secara teknis merupakan gabungan dari tari tiga sambut yang berasal dari suku yang ada di wilayah Kota Prabumulih diantaranya: Suku Blide tari tupai begelut, Suku Rambang tari Sembilan bidadari, Suku Lematang tari pincang urung. Tarian ini ditarikan secara kelompok dengan jumlah penari ganjil ditambah 2 pengawal dan 1 pelindung untuk menyaksikan pertunjukan dengan penonton yang berbentuk melingkar.

Asal-usul musik gamelan ini kurang lebih sudah 400 tahun yang lalu cerita dari Bpk. Ajadin salah satu sesepuh Kota Prabumulih juga tokoh adat keturun kiriye yang paham kesenian yang ada di Kota Prabumulih. Musik gamelan ini memilki jumlah pemain 5 orang. Adapun tempat penyajian dalam musik gamelan pada penyajain tari seinggok sepemunyian bisa diluar dan di dalam ruangan. Alat musik gamelan ini ada beberapa macam gong, gendang muka dua, tawak-tawak, dan kenong kemudian kendala untuk membuat gamelan yang asli tidak ada maka dari itu gamelan ini tetap dipertahankan sampai saat ini.

Pada bentuk penyajian musik Gamelan pada tari seinggok sepemunyian memiliki 4 macam alat musik gamelan yang terdiri dari Gong, kenong, tawak-tawak, dan gendang muka dua yang memiliki susunan konsep. Waktu dalam penyajian musik gamelan ini tergantung lokasi pemainnya dan penonton menyaksikan membentuk melingkar. Kata Konsep berasal dari bahas latin conceptum, yang artinya sesuatu yang dipahami. Aristoteles dalam bukunya "The classical theory of conceptum" menyatakan bahwa konsep merupakan penyusun utama dalam pembentukan pengetahuan ilmiah dan filsafat pemikiran manusia. Jadi konsep musik adalah gagasan utama atau dasar utama dalam pembentukan irama yang dihasilkan dari suara alat-alat yang menghasilkan irama.

\section{Tabel 1 : Bentuk Penyajian Musik Gamelan Pada Tari Seinggok Sepemunyian Di Sanggar Seinggok Sepemunyian Kota Prabumulih}

\begin{tabular}{|c|c|}
\hline No & $\begin{array}{c}\text { Bentuk Penyajian Musik Gamelan Pada } \\
\text { Tari Seinggok Sepemunyian }\end{array}$ \\
\hline 1 & $\begin{array}{l}\text { Bagian awal penyajian musik gamelan pada } \\
\text { tari seinggok sepemunyian ini diawali } \\
\text { dengan penari dan pemusikyang telah } \\
\text { membentuk formasi sebelum dimulainya } \\
\text { pertunjukan. }\end{array}$ \\
\hline 2 & $\begin{array}{l}\text { Bagian inti dari bentuk penyajian musik } \\
\text { gamelan pada tari seinggok sepemunyian }\end{array}$ \\
& adalah terletak pada penari dan pemusik \\
& $\begin{array}{l}\text { yang dimulai dengan pukulan alat musik } \\
\text { kenong saja dan dijadikan penanda bahwa }\end{array}$ \\
& $\begin{array}{l}\text { pasukan penari dan pemusik akan segera } \\
\text { dimulai. Tarian ini hampir seluruhnya }\end{array}$ \\
& menggunakan gerakan penggulangan yang \\
& dilakukakan penari, yaitu ragam gerak \\
& maju mundur, meliuk penuh, picang urung, \\
& Sembilan bidadari begitu pula juga dengan \\
pemusik sama saja dengan penari yang & melakukan penggulagan musik yang \\
& menggiringi penari hanya menggunkan \\
instrument musik saja yaitu kenong, gong, & tawak-tawak dan gendang muka dua. \\
\hline 3 & $\begin{array}{l}\text { Bagian ahkir dari bentuk penyajian musik } \\
\text { gamelan pada tari seinggok sepemuyian ini } \\
\text { telah di sajikan dari awal sampai ahkir, } \\
\text { penyajian pun berahkir sebelum pasukan } \\
\text { penari tari seinggok sepemunyian } \\
\text { mengahkiri penyajiannya alat musik } \\
\text { kenong pun memberi aba-aba akan } \\
\text { berahkirnya penyajian. }\end{array}$ \\
\hline
\end{tabular}

\section{Kesimpulan}

Bentuk Penyajian Musik Gamelan Pada Tari Seinggok Sepemunyian Di Sanggar Seinggok Sepemunyian Kota Prabumulih, dapat dikatakan alat musik gamelan ini yaitu alat musik pukul yang biasa disajikan pada saat acara penyambutan tamu agung, 
acara pernikahan, dan persta rakyat. Bentuk penyajian musik gamelan ini adalah ensambel musik yang dimaiankan kurang lebih 5 pemusik dan 3 orang penari. Hasil Penelitian ini bahwa bentuk penyajian musik gamelan pada tari seinggok sepemunyian itu sendiri terdapat tahap-tahapan prosesnya yaitu dari awal sajian musik gamelan dimulai hingga ahkir penyajian musik dan tarian selesai dengan terdapat konsep musik dalam penyajiannya yaitu seperti gong, kenong, tawak-tawak, gendang muka dua yang menggiringi tari seinggok sepemunyian adapun untuk menyaksikan pertunjukan yang sedang di tampilkan biasanya disajikan diruang terbuka dan tertutup dengan penonton yang berbentuk melingkar.

\section{Saran}

Musik Gamelan merupakan kearifan lokal yang harus dijaga dan dilestarikan. Maka akan baiknya jika.

1. Bagi Masyarakat

Hasil Penelitian ini diharapkan berguna dan bermanfaat, terutama bagi peneliti sendiri, sehingga dapat menggembangkan wawasan tentang bentuk penyajian musik gamelan pada tari seinggok sepemunyian di sanggar seinggok sepemunyian Kota Prabumulih.

2. Bagi Insitusi Pendidikan

Hasil Penelitian ini diharapkan dapat memberikan konstribusi terhadap pengembangan ilmu pengetahuan yang berkaitan dengen bentuk penyajian musik gamelan pada tari seinggok sepemunyian di sanggar seinggok sepemunyian Kota Prabumulih.

3. Mahasiswa Seni Musik

Hasil penelitian ini diharapkan dapat dimanfaatkan dalam upaya meningkatkan eksitensi dan menambah bahan pembelajaran mengenai musik gamelan pada tari seinggok sepemunyian di Kota Prabumulih.

4. Bagi Peneliti

Diharapkan menambah wawasan pengetahuan tentang penyajian musik gamelan pada tari seinggok sepemunyian di Kota Prabumulih serta melestarikan dan menjaga kesenian gamelan agar tetap terjaga dan dapat dikenal masyarakat luas.

\section{DAFTAR PUSTAKA}

Banoe, P. (2003). Kamus Musik. Yogyakarta: Kanisius. Indonesia, E. N. (1996). Ensiklopedi National Indonesia. Jakarta: PT Cipta Adi Pustaka.

Kusumawati, H. (2004). PENYIMPANGAN PADA PENULISAN LAGU POPULER KAJIAN SINKRONISASI ANTARA FRASE MELODI DAN TEKS LAGU. Imaji: Jurnal Seni dan Pendidikan Seni, 1.

Mardalis. (1995). Metode Penelitian SuatuPendekatan Proposal. Jakarta: Bumi Aksara.

Mudjilah, H. S. (2004). Teori Musik Dasar. Yogyakarta: Universitas Negeri Yogyakarta, 7.

Nasional, D. P. (1988). Kamus Besar Bahasa Indonesia. Jakarta: Balai Pustaka.

Oktara, B. (2011). JagoTeknik Vocal. Jakarta Timur: PT Buku Kita.
Salim, P. s. (1991). Kamus Bahasa Indonesia Kontemporer. Jakarta: Modern English.

Sedyawati, E. (1992). Pertumbuhan Seni Pertunjukan. Jakarta: Sinar Harapan.

Soeharto, M. (1992). Kamus Musik. Jakarta: Gramedia widia sarana Indonesia.

Sugiyono. (2015). Metode Penelitian Kombinasi (Mix Methods). Bandung: Alfabeta.

Sugiyono. (2018). Metode Penelitian Kombinasi (Mixed Methods). Bandung: CV Alfabeta.

Tumbijo, H. (1977). Minangkabau Dalam Seputar Seni Tradisional. Padang: SMSR.

Wardhana. (1990). Pendidikan SeniTari Buku Guru Sekolah Menengah Atas. Jakarta: Gudang Ilmu.

Waridi. (2005). Menimbang Pendekatan Pengkajian dan Penciptaan Musik Nusantara. Surakarta: STSI. 